\title{
A pénzügyi ösztönzők hatása az egyetemi oktatók osztályozási gyakorlatára
}

Kutatásunk célja annak vizsgálata, hogy az egyetemi oktatók hallgatói véleményezési rendszerben kapott értékelésének anyagi díjazása hogyan hat az osztályzatokra. Elemzésünk alapját egy magyarországi egyetem szabályozásváltozása okozta természetes kísérlet adja, amelyben a (közvetett) pénzügyi ösztönző bevezetése csak a teljes állású oktatókra vonatkozott, a részmunkaidős és külsős oktatók esetén nem történt változás. Az elemzést a különbségek különbsége módszer logikája alapján, tantárgy-oktató fix hatást tartalmazó panelregresszió segítségével végeztük el. Eredményeink alapján a pénzügyi ösztönző bevezetése szignifikánsan növelte az érdemjegyek átlagát az alacsony átlagos érdemjegyekkel jellemezhető kurzusokon. Az átlagos érdemjegy javulásában jelentős szerepet játszott a tantárgyi követelményeket sikeresen teljesítő hallgatók arányának növekedése. Az eredmények konzisztensek a jegyinfláció jelenségével, ugyanakkor nem zárható ki, hogy a jobb osztályzatoknak az oktatók jobb felkészültsége és nagyobb odafigyelése az oka, amit szintén erősíthetett az új pénzügyi ösztönző rendszer.* Journal of Economic Literature (JEL) kód: C20, I23, I28.

\section{Bevezetés}

Az elmúlt évtizedekben a hallgatók egyre kevesebb időt töltenek tanulással, mégis egyre jobb jegyeket kapnak, és egyre jobb átlaggal végeznek (Stroebe [2016], Babcock-Marks [2011]). Ezt a jelenséget nevezik jegyinflációnak. Rojstaczer [2016]

* Köszönettel tartozunk Hermann Zoltánnak, Horn Dánielnek, Kováts Gergelynek, Sebestyén Imrének és az anonim opponensnek a tanulmány elkészítéséhez nyújtott segítségükért, javaslataikért. Berezvai Zombor kutatása az Emberi Erőforrások Minisztériuma ÚNKP-18-3 kódszámú Új Nemzeti Kiválóság Programjának támogatásával készült.

Berezvai Zombor PhD-hallgató, Budapesti Corvinus Egyetem Gazdálkodástani Doktori Iskola (e-mail: zombor.berezvai@uni-corvinus.hu).

Lukáts Gergely Dániel MSc-hallgató, Budapesti Műszaki és Gazdaságtudományi Egyetem Matematika Intézet (e-mail: lukatsgd@math.bme.hu).

Molontay Roland tudományos segédmunkatárs, MTA-BME Sztochasztika Kutatócsoport, Budapesti Müszaki és Gazdaságtudományi Egyetem Sztochasztika Tanszék (e-mail: molontay@math.bme.hu). A kézirat első változata 2019. február 14-én érkezett szerkesztőségünkbe.

DOI: http://dx.doi.org/10.18414/KSZ.2019.7-8.733 
egyesült államokbeli magán- és állami egyetemek adatai alapján kimutatta, hogy az átlagjegyek (Grade Point Average, GPA) megközelítőleg 0,10-0,15-dal nőttek évtizedenként. ${ }^{1}$ Wilson [1999] rámutatott, hogy a Harvard Egyetemen az $A$ (jelesnek megfelelö) jegyek aránya az 1966-os 22 százalékról 1997-re 46 százalékra nőtt, ennek eredményeként 2001-ben már a hallgatók 91 százaléka kitüntetéssel végzett a Harvardon. A jegyinfláció tehát jegykompressziót okoz a jegyeloszlás felső tartományában, így kevésbé tudnak a legtehetségesebb hallgatók kitűnni (Korn [2018]). Bár a jegyinfláció a magánegyetemek esetében a leglátványosabb, állami intézményekben szintén megfigyelhető. Eiszler [2002] egy neves egyesült államokbeli állami egyetem két évtizednyi adatát elemezve szintén arra a következtetésre jutott, hogy az $A$ érdemjegyre számító hallgatók aránya szignifikánsan növekedett a vizsgált időintervallumban.

A jegyinfláció pontos okai és mechanizmusai vitatottak, de sokan úgy vélik (Isely-Singh [2005], Nowell [2007], Jewell és szerzőtársai [2013]), hogy az oktatás hallgatói véleményezésének növekvő súlya - mind társadalmi, mind pénzügyi értelemben - az egyik jelentős oka a jegyinfláció jelenségének. A minőségi felsőoktatás egyik alapköve az egyetemi oktatók magas színvonalú oktatók tevékenysége, ezért az egyetemek minőségbiztosítási céllal folyamatosan nyomon követik az oktatás minőségét. Ennek egyik legelterjedtebb formája az oktatók hallgatói véleményezése, amelynek használata ugyan számos kérdést vet fel, de a 20. században egyre inkább az egyetemi oktatási minőség legmeghatározóbb tényezőjévé vált. Az Egyesült Államokban 1973-ról 1993-ra például 29 százalékról 86 százalékra nőtt azon felsőoktatási intézmények aránya, amelyek az oktatói munka értékelése során támaszkodnak a hallgatói véleményezésekre (Seldin [1998]). Ma már a felsőoktatási intézmények túlnyomó többségében használják ezt az értékelési formát, illetve a legtöbb egyetemen a hallgatók által adott értékelések fontos szerepet játszanak az egyetemi oktatók előléptetésében, jutalmazásában is.

Széles körü elterjedtsége ellenére erösen vitatott, hogy mennyire lehet támaszkodni az oktatás minőségének megítélése során a hallgatói véleményekre. Számos tanulmány (Boring és szerzőtársai [2016], Hornstein [2017], Boring [2017]) kimutatta, hogy az olyan, oktatási szempontból irreleváns tényezők, mint a nem, a kor vagy a vonzó megjelenés, erős korrelációt mutatnak a hallgatói értékelés során kapott pontszámokkal. Youmans-Jee [2007] megfigyelte, hogy ha az oktatói véleményezés kitöltése elött a hallgatók csokoládét kapnak, akkor szignifikánsan jobb értékelést adnak, mint a kontrollcsoport. Továbbá a kurzus jellemzői - például a tudományág, a kreditérték, a csoportméret - szintén befolyásolják a hallgatói értékelést. Több kutatás is kimutatta, hogy a nagy csoportméret negatív hatással van az oktató értékelésére (Andrade-Rocha [2012], Cho-Cho [2017], Ewing [2012]).

Sokan megkérdőjelezik azt is, hogy a hallgatói értékelések egyáltalán valóban az oktatás minőségét mérik-e (Alauddin-Kifle [2014], Boring és szerzőtársai [2016], Hornstein [2017], Boring [2017]). Ware-Williams [1975] híres kísérletében egy színészt kértek fel arra, hogy tartson egy teljesen összefüggéstelen előadást

\footnotetext{
${ }^{1}$ Ötfokozatú skálán mérve az érdemjegyeket.
} 
játékelméletről, de azt lebilincselő és lelkesítő módon tegye, majd felkérték az előadás megtartására a téma egyik szakértőjét is. A színész ugyanolyan magas értékeléseket kapott, mint a tudós. Andrade-Rocha [2012] brazíliai adatokon vizsgálódva azt találta, hogy az oktatásmódszertani továbbképzésen áteső oktatók sem kaptak jobb hallgatói értékeléseket.

Számos vita övezi azt is, hogy mi a megfelelő módja az oktatói munka hallgatói véleményezésének. Az intézményenként használt különböző módszerek és kérdések pedig megnehezítik az eredmények összevetését. Bizonyos egyetemeken az érdemjegy kézhezvétele előtt kell az oktatót értékelni, máshol erre utána van mód. Van, ahol a kitöltés kötelezö, ami nem elég gondos válaszadáshoz vezethet, máshol a kitöltés opcionális, ami viszont nem reprezentatív eredményeket hozhat (Stark [2013]). Vitatott az is, hogy a papíralapú vagy az online kitöltés a hatékonyabb, illetve az is, hogy hány kérdést és milyen megfogalmazásban kell feltenni, hogy a legmegbízhatóbb eredményeket kapjuk (Nowell és szerzötársai [2010], Spooren és szerzőtársai [2013]).

Tekintettel arra, hogy a hallgatói értékelések eredményei számos egyetem esetében fontos tényezők az előléptetés és a javadalmazás során, így az oktatók erősen ösztönözve vannak a minél jobb hallgatói értékelés elérésében. A jobb oktatási teljesítményre való törekvés helyett azonban lehetnek olyan oktatók is, akik a tanulmányi követelmények enyhítésében és jobb jegyek odaítélésében látják a kedvezőbb hallgatói értékelések megszerzésének lehetőségét.

A hallgatói értékelések eredményei és a jegyinfláció kapcsolatának vizsgálata központi kutatási kérdéssé vált. Számos tanulmány kimutatta (Isely-Singh [2005], Nowell [2007], McPherson és szerzötársai [2009], Ewing [2012]), hogy erös pozitív korreláció van a hallgató által adott értékelés és az oktatótól kapott jegy között. Ugyanakkor nagyon nehezen állapítható meg az, hogy az oktató által adott jobb jegyek az engedékenységből fakadnak, vagy a tanár valóban színvonalas és hatékony oktatási teljesítménye miatt születnek. Ideális esetben egy felkészült oktató kurzusára járó hallgatók jobb vizsgaeredményeket érnek el, azaz jobb jegyeket kapnak, és jobb értékeléseket is adnak az oktatónak - a jobb oktatási tevékenységet jutalmazva, nem pedig az engedékeny osztályozást.

Ewing [2012] a Washingtoni Egyetem adatain kimutatta, hogy a jegy egységnyi növekedése 0,3-0,7 egységnyivel (tanszéktől és modellspecifikációtól függően) növeli a hallgatók oktatóra adott értékelését. Bár a jegyinfláció és a hallgatói értékelések összefüggését vizsgáló kutatást egyesült államokbeli adatokon végezték, szép számmal találunk hasonló tanulmányokat szerte a világban. Cho-Cho [2017] dél-koreai adatokon vizsgálta, hogy mennyire befolyásolja a hallgatói értékeléseket az, hogy a diákok tisztában vannak-e a végső érdemjegyükkel. Davies és szerzötársai [2007] ausztrál adatokon kimutatta, hogy a hallgatói véleményeket nagyban befolyásolják olyan tényezök (például nem, kor, csoportlétszám), amelyekre az oktatónak nincsen ráhatása. Macfadyen és szerzőtársai [2016] kanadai adatokon vizsgálta, hogy milyen tényezők befolyásolják, hogy a hallgatók kitöltik-e az oktatókra vonatkozó kérdőíveket. Bauer-Grave [2011] egy német egyetem adatait elemezve arra jutott, hogy bár egy oktatáspolitikai reform következtében a német egyetemek finanszírozása részben 
függővé vált az oktatás hallgatói érékelésének eredményétől, ez mégsem vezetett szignifikáns jegyinflációhoz.

Hazai elemzések is készültek a témában (Berezvai [2018], Lukáts [2019]), amelyek szintén alátámasztják az érdemjegy és a hallgatói véleményezés közötti pozitív kapcsolatot. A hatás nagysága is összhangban van a nemzetközi eredményekkel.

Az akadémiai kutatások eredményeit alátámasztja, hogy egyes egyetemek elkezdték felvenni a harcot a jegyinflációval. Az amerikai Wellesley College felismerte, hogy az egyre javuló jegyek mögött nem feltétlenül valós teljesítmények állnak, és megpróbálta megállítani a folyamatot. Egy szabályozással kimondta, hogy a legalább 10 diákkal rendelkező kurzusokon az átlagos osztályzat nem haladhatja meg a 3,33-ot, ${ }^{2}$ aminek hatására valóban csökkentek az átlagos érdemjegyek a szabályozás által érintett kurzusokon (Butcher és szerzőtársai [2014]).

Jelen kutatásunk célja annak vizsgálata, hogy a hallgatói értékeléshez kapcsolt pénzügyi ösztönzők kapcsolatba hozhatók-e a jegyinflációval. Elemzésünket egy magyarországi egyetem adatain végeztük el. Kutatásunk egyedülálló abból a szempontból, hogy a vizsgált egyetem szabályozásváltozása egy természetes kísérletet tett lehetővé, amelynek során meg tudtuk vizsgálni, hogy azon oktatók esetében, akiknél a jó hallgatói értékelés elérése pénzbeli juttatást is von maga után, átlagosan menynyivel javultak a jegyek az olyan oktatókhoz képest, akiknél a jó hallgatói értékelés nem járt közvetlen anyagi előnyökkel. Jelen tanulmány tehát egyedülálló módon azt járja körül, hogy a pénzügyi ösztönzők milyen hatással vannak az oktatók osztályozási gyakorlatára, és ez mennyiben hat a jegyinflációra.

\section{A szabályozás bemutatása}

A vizsgált egyetemen az oktatók és kutatók munkáját évről évre a teljesítményértékelési rendszer (TÉR) keretében minősítik. A TÉR-ben helyet kapnak az oktatás és a kutatás mennyiségi (például oktatott órák száma) és minőségi (például elfogadott cikkek folyóiratának besorolása) szempontjai is. Az oktatás minőségének egyik mérőszáma a hallgatói véleményezési rendszerben elért pontszám. Ez a pontszám az oktatók hallgatói értékelését tükrözi, 1-5-ös skálán mérve.

A TÉR-ben munkakörönként eltérő, hogy minimálisan mennyit kell teljesíteni: tanársegédek esetében ez 150 pont, míg egyetemi tanárok esetén 180 pont. A hallgatói véleményezési rendszerben elért értékelés alapján félévente maximum 10 pont (összesen tehát 20 pont) szerezhető meg, azonban ez nem lineáris, az alábbi képlet alapján határozódik meg az értéke:

TÉR-pont $=\max \left(\frac{\text { hallgatói értékelés }-3,5}{0,15}, 0\right)$,

tehát csak azok az oktatók kaphatnak pontot ezen a jogcímen, akiknek az összesített hallgatói véleményezési értékelése legalább 3,5 volt az adott félévben.

\footnotetext{
${ }^{2}$ A vizsgált egyetemen 0 és 4 közötti osztályozási skálát használtak.
} 
A TÉR értékelési rendszer régóta létezik, azonban az elért pontnak (amennyiben az az elvárt minimum fölött volt) nem volt következménye. Ezen módosított az egyetem szenátusa 2016 májusában, amikor elfogadta a teljesítménymérésen alapuló, differenciált javadalmazási rendszer bevezetését az intézményben. 2017-től kezdődően az előző éves teljesítmény (TÉR-pontszám) alapján jövedelemkiegészítésben részesülnek a teljes állású munkaviszonyban lévő munkatársak. A kiegészítő jövedelem mértékét sávosan állapították meg oly módon, hogy az adott munkavállaló által elért TÉR-pontszám a minimumkövetelmény hány százaléka volt. A jövedelemkiegészítés mértéke havonta viszonylag jelentős összeg (elérheti, sőt meg is haladhatja a bruttó bér nagyságát), tehát innentől kezdve fontossá vált a TÉR és az ott elért pontszám.

Mindez implicit módon azt jelenti, hogy a hallgatói véleményezésen elért értékelés lefordíthatóvá vált konkrét jövedelemmé, tehát minden teljes állású oktató anyagilag is érdekeltté vált a hallgatói véleményezésen elért értékelés javításában. Ugyanakkor a részmunkaidős vagy külsős oktatók, demonstrátorok, illetve PhDhallgatók esetén nem változott a korábbi állapot, hiszen esetükben nem releváns a differenciált javadalmazási rendszer.

Mint az a korábbi kutatásokból is kiderült (például Ewing [2012], Cho-Cho [2017], Davies és szerzőtársai [2007]), a kapott érdemjegy és a hallgatói értékelés pontszáma között viszonylag erős kapcsolat fedezhető fel. Hazai elemzések (Berezvai [2018], Lukáts [2019]) is alátámasztják, hogy a jelenség Magyarországon is megfigyelhető, és nagyságrendjében hasonló az amerikai adatokon mért hatásokhoz. Ebben a helyzetben érdekes kérdés, hogy a teljesítménymérésen alapuló differenciált javadalmazási rendszer bevezetése növelte-e a jegyinflációt az egyetemen.

\section{Adatok}

A kutatáshoz az alapszakos nappali képzésben meghirdetett tantárgyak adatait használtuk a 2013/2014. tanévtől a 2017/2018. tanévig. A vizsgálat során kizárólag a tavaszi félévet elemeztük, így összesen öt félévet vizsgáltunk. Az adatbázis szükítésére több tényezö miatt is szükség volt.

A hallgatói képességekre a felvételi pontszámmal kontrolláltunk, ez pedig csak az alapszakos hallgatók esetén kerül standardizált módon megállapításra, lehetővé téve a pontszámok összevetését. A nappali tagozatos tárgyakra való szürés oka az volt, hogy a hallgatói véleményezési rendszert alapvetően a nappali tagozatos hallgatók töltik ki, így a szabályozásváltozás hatásai itt érződnek a legnagyobb mértékben.

Végezetül, három szempont alapján döntöttünk a tavaszi féléves tárgyak elemzése mellett. Egyrészt, alapszakos képzésben nincs keresztféléves felvételi, emiatt pedig a legtöbb tantárgyat tanévenként egyszer (vagy az őszi, vagy a tavaszi félévben) hirdetik meg. Az öszi félév beemelése a mintába tehát nem növelte volna az idősor hoszszát. Másrészt, az új javadalmazási rendszert 2016 májusában fogadta el az egyetem szenátusa, azonban csak 2016 őszén került kihirdetésre, az első kifizetések pedig 2017ben történtek meg. A 2016/2017. tanév őszi szemeszterében tehát az oktatók egy része már tudhatott az új rendszerről, egy részük viszont még biztosan nem, és gyakorlati 
tapasztalata senkinek sem volt még róla. Emiatt ezt az átmeneti félévet mindenképp érdemes kihagyni a mintából, ez viszont megtöri az őszi féléves adatsor folytonosságát. Harmadrészt, alapszakos képzésben az őszi félév mindig az első félév. Az egyetemi lemorzsolódás döntően az első félévben történik, ${ }^{3}$ aminek kihatása lehet a hallgatói véleményezésre is. Az eredmények robusztusságának vizsgálatakor ugyanakkor az őszi féléves adatokat is beemeltük az elemzésbe, a 2016/2017. tanév kivételével.

A tárgyak közül csak az érdemjeggyel záruló tárgyakat vettük figyelembe. Azokat a tárgyakat, ahol a teljesítés végső követelménye aláírás volt, kiszűrtük a mintából. Emellett a 0 kredites és a 10-nél több kreditet érő tárgyakat is kivettük a mintából. A 10 kreditnél többet érő tárgyak nem hagyományos egyetemi tárgyak (például szakszemináriumok, szakmai gyakorlatok), amelyek torzítanák a mintát. Emellett az 5 főnél alacsonyabb létszámú tárgyakat szintén nem elemeztük.

$\mathrm{Az}$ anonimizált hallgatói szintű adatokból elsőként kiszürtük azokat az eseteket, amikor a hallgató nem az egyetemen végezte el a tárgyat, hanem külföldön vagy más hazai egyetemen teljesítette azt, és tárgyelfogadtatás keretében kapott érte érdemjegyet. Ezekben az esetekben az oktatónak nem volt befolyása az érdemjegyre, a hallgató nem is járt órára, tehát a vizsgálat szempontjából torzítaná a mintát.

A hallgatók kvalitásaira a központi egyetemi felvételi eljárás során elért pontszámukkal kontrolláltunk. Azért esett erre a választásunk, mert a felvételi eljárás és a pontszám számítási módszertana országosan szabályozott, és az egységes kétszintü érettségi vizsgára épül. Azokat a hallgatókat, akiknél hiányzott a felvételi pontszám, nem vettük figyelembe az elemzés során. Azoknál a hallgatóknál, akik 2012 előtt felvételiztek egyetemre, amikor még nem 500 pont volt a maximálisan elérhető felvételi pontszám (hanem 144 vagy 480), arányosítottuk a pontokat.

Az elvégzett adattisztítások után tantárgy-oktató párokra aggregáltuk az adatokat (félévenként). A tantárgy-oktató párok használata mögötti elgondolás az volt, hogy az egyes tantárgyak felépítése, nehézsége eltérö, azonban az egyes oktatók adott tantárgyak iránti érdeklődése, elkötelezettsége is változó. Lehetséges, hogy egy adott oktató egy adott tantárgyat nagyon kedvel, és emiatt jó órákat tart belőle, míg más tárgyak esetén kisebb a lelkesedése, és ez kihathat a teljesítményére is. Az adatok panelstruktúrája miatt a vizsgált félévekben végig tudtuk követni, hogy az adott tantárgy-oktató párok esetén hogyan alakultak az átlagos érdemjegyek, illetve az érdemjegyek eloszlása (ezek közül a nem teljesítők arányát vizsgáltuk részletesebben).

Az így kialakított adatbázis 4289 tantárgy-oktató-félév hármast tartalmazott. Az egyes változók leíró statisztikáit az 1. táblázat tartalmazza.

A minta egy része ugyanakkor olyan tantárgy-oktató párokat tartalmaz, amelyek a vizsgált öt évből mindössze néhányban jelentek meg. Kutatásunk során ezért elsősorban arra a részmintára összpontosítottunk, ahol a tantárgy-oktató párok legalább négyszer megjelentek úgy, hogy az oktató ugyanúgy teljes állású vagy nem teljes állású volt mindegyik alkalommal. Ez 1811-re csökkentette a mintaelemszámot. Cserébe viszont olyan adatsokaságon végeztük az elemzést, amelyben a vizsgált oktatók majdnem minden évben tanították ugyanazt a tantárgyat, tehát az osztályozásban

\footnotetext{
${ }^{3}$ A lemorzsolódási mutatókat az egyetem saját, illetve az Oktatási Hivatal elemzései is megerősítik.
} 
1. táblázat

Változók leíró statisztikája a teljes mintán (4289 tantárgy-oktató-félév hármas értékei alapján)

\begin{tabular}{lrrccc}
\hline Változó & Minimum & Maximum & Átlag & Medián & Szórás \\
\hline Átlagos érdemjegy & 1 & 5 & 3,82 & 3,92 & 0,78 \\
A tárgyat teljesítők aránya & 0 & 1 & 0,94 & 0,99 & 0,10 \\
Az oktató kora & 20 & 77 & 43 & 42 & 11,4 \\
Átlagos felvételi pont & 349 & 488 & 440 & 446 & 22 \\
Kredit & 2 & 10 & 4,5 & 5 & 1,3 \\
Létszám & 5 & 1863 & 68 & 41 & 94 \\
\hline
\end{tabular}

Kétértékű változók (százalék)

Teljes állású 71

Oktató neme (nő) 40

Gyakorlati kurzus 64

Vizsga 68

lévő eltérések jól vizsgálhatók. A szűkített minta leíró statisztikáit a 2. táblázat tartalmazza. Jelentősebb eltérés csak a teljes állású oktatók arányában és a létszámban látható. Ezek logikus változások, hiszen a mindössze egy vagy néhány szemeszterben oktatók nagy része nem teljes állású alkalmazott, hanem óraadó, demonstrátor vagy éppen $\mathrm{PhD}$-hallgató. Emellett pedig a nagy létszámú kurzusok általában a kötelező és/vagy népszerủ tárgyak, amelyeket minden tanévben meghirdetnek, és el is indulnak. Az újonnan induló vagy éppen megszünő tárgyak esetén a létszám kisebb.

\section{2. táblázat}

Változók leíró statisztikája a szükített mintán (1811 tantárgy-oktató-félév hármas értékei alapján)

\begin{tabular}{lccccc}
\hline Változó & Minimum & Maximum & Átlag & Medián & Szórás \\
\hline Átlagos érdemjegy & 1,64 & 5 & 3,84 & 3,91 & 0,72 \\
A tárgyat teljesítők aránya & 0,48 & 1 & 0,95 & 0,99 & 0,08 \\
Az oktató kora & 21 & 71 & 45 & 44 & 10,4 \\
Átlagos felvételi pont & 364 & 488 & 443 & 449 & 20 \\
Kredit & 2 & 9 & 4,4 & 4 & 1,1 \\
Létszám & 5 & 1863 & 82 & 51 & 116 \\
\hline
\end{tabular}

Kétértékü változók (százalék)

Teljes állású

Oktató neme (nő)

Gyakorlati kurzus 


\section{Kutatási módszertan}

Elemzésünk során a különbségek különbsége (difference-in-difference) módszertan logikáját követtük a pénzügyi ösztönzők és az érdemjegyek közötti kapcsolat számszerüsítése érdekében. A módszer lényege, hogy a sokaságot két csoportra osztottuk, egy kezelés által érintett, valamint egy nem érintett alsokaságra. Elsőként megvizsgáltuk, hogy a kezelt és nem kezelt sokaság milyen eltéréseket mutatott a kezelés elött, majd a kezelés után. A két csoport közötti eltérések változása (a különbségek különbsége) mutatja a kezelés hatását.

A különbségek különbsége módszert gyakran használják azokban az esetekben, amikor egy szabályváltozás nem érinti a teljes sokaságot. Meyer és szerzőtársai [1995] Kentucky és Michigan államok esetében vizsgálta, hogy miként hatott a táppénz felső határának megemelése a táppénzen töltött időtartam hosszára. Elemzésük alapja, hogy az alacsony fizetésủ munkavállalók esetén a szabályozás nem hozott semmilyen változást, így ők megfelelő kontrollcsoportot képeztek a magas fizetéssel rendelkező, emiatt a szabályozás által érintett kezelt populációhoz. ElekLörincz [2015] az effektív társasági adókulcs rugalmasságát vizsgálta hasonló módszerrel, kihasználva, hogy az adókedvezményben részesülő cégek számára az adócsökkentés előtt is alacsonyabb volt a társasági adókulcs. A jegyinflációval kapcsolatos irodalomban is többször elökerül a különbségek különbsége módszertan alkalmazása (például Butcher és szerzőtársai [2014]).

Jelen kutatás során azt használtuk ki, hogy a teljesítményalapú keresetkiegészítés csak a teljes állású alkalmazottakra vonatkozik, a részmunkaidős és külsős oktatók nem részesülhetnek belőle. Emiatt a hallgatói véleményezési eredmények csak a teljes állású alkalmazottak esetén jelenthetnek magasabb keresetkiegészítést, a többi oktató esetében nem járnak semmilyen pénzügyi ösztönzővel. A részmunkaidős és külsős oktatók tehát megfelelő kontrollcsoportot alkotnak a különbségek különbsége módszer alkalmazásához.

$\mathrm{Az}$ adatbázis tantárgy-oktató párokat tartalmaz, tehát azt mutatja meg, hogy egy adott oktató adott tantárgyból milyen osztályzatokat adott négy-öt egymást követő tanévben. Az adatbázis felépítéséből következően tehát tantárgy-oktató fix hatások alkalmazásával tudunk kontrollálni az adott tantárgyra és oktatóra jellemző minden időben állandó hatásra. Ezek egy része (oktatóknál például a nem és a születési év, tantárgyaknál a kreditérték és a számonkérés módja) megfigyelhető, míg más része nem (például oktatási képesség). Az alkalmazott módszertan előnye, hogy nem tételezi fel azt, hogy egy adott oktató minden tantárgya tanításánál ugyanúgy viselkedik, ami összhangban van a valósággal. Mindössze azzal a megszorítással él a modell, hogy időben nem változnak az adott oktató adott tantárgyra vonatkozó nem megfigyelhető változói.

Az elemzés során egyéb kontrollváltozókat is szerepeltettünk a modellben. A kontrollváltozókat korábbi tanulmányok alapján határoztuk meg (Ewing [2012], Cheng [2015]), majd a magyar gyakorlatnak és az elérhető adatoknak megfelelően választottuk meg. A fixhatás-modellkeret miatt egyedül az időben változó hatások szerepeltetése lehetséges, így három hatást építettünk be a modellbe. Egyrészt, a diákok kvalitásaira, képességeire és szorgalmára vonatkozóan az egységes egyetemi felvételi 
rendszerben elért pontszámukat használtuk. Másrészt, a kurzus méretére az adott oktató adott tantárgyát hallgató diákok számának logaritmusával kontrolláltunk. Végezetül, beépítettünk szemeszter kétértékü (dummy) változókat, hogy az általános jegyinfláció jelenségét meg tudjuk ragadni, és ettől meg tudjuk szürni a modellt. A becsült modell az (1) formát öltötte:

$y_{i t}=\alpha+\beta$ JoGOSULT $_{i t}+\delta X_{i t}+D_{t}+c_{i}+u_{i t}$,

ahol $y_{i t}$ az $i$-edik tantárgy-oktató pár átlagos osztályzata vagy teljesítési aránya a $t$-edik szemeszterben, a JoGosult ${ }_{i t}$ pedig azt mutatja, hogy az adott oktató a $t$-edik szemeszterben jogosult volt-e a differenciált javadalmazási rendszeren alapuló keresetkiegészítésre. Ez akkor teljesül (tehát a változó akkor vesz fel 1 értéket), ha teljes állású, és bevezették már az új javadalmazási rendszert (tehát a 2016/2017. tanévtől kezdődően). Az általános jegyinflációt pedig a szemeszter kétértékủ változókkal $\left(D_{t}\right)$ ragadtuk meg. Az $X_{i t}$ a kontrollváltozókat tartalmazza (átlagos egyetemi felvételi pontszám és létszám), míg $c_{i}$ a tantárgy-oktató fix hatásokat. Végezetül pedig $u_{i t}$ a véletlen hibatagot jelöli.

Az adatbázisban csak olyan tantárgy-oktató párok szerepelnek, amelyeknél az oktató végig vagy teljes állású, vagy nem teljes állású volt. Emiatt az oktató állása időben állandó, vagyis a fix hatás ezt is tartalmazza, tehát nem szerepeltethető külön a modellben. Ez eltérést okoz a hagyományos különbségek különbsége módszertől.

A kutatás szempontjából érdekes paraméter a $\beta$, amely azt mutatja meg, hogy azoknál az oktatóknál, akik jogosulttá váltak a teljesítményalapú keresetkiegészítésre, hogyan változtak az érdemjegyek, illetve a bukási arány azokhoz képest, akik nem váltak jogosulttá.

A becslés során a kezelt és nem kezelt csoportok minél jobb párosítása érdekében az elemzést többféle módon is lefuttattuk. Egyrészt, megkülönböztettük az

\section{1. ábra.}

Az egyes osztályozási csoportokban lévő tantárgy-oktató párok száma a szűkített mintában (külső kör: teljes állásúak; belső kör: nem teljes állásúak)

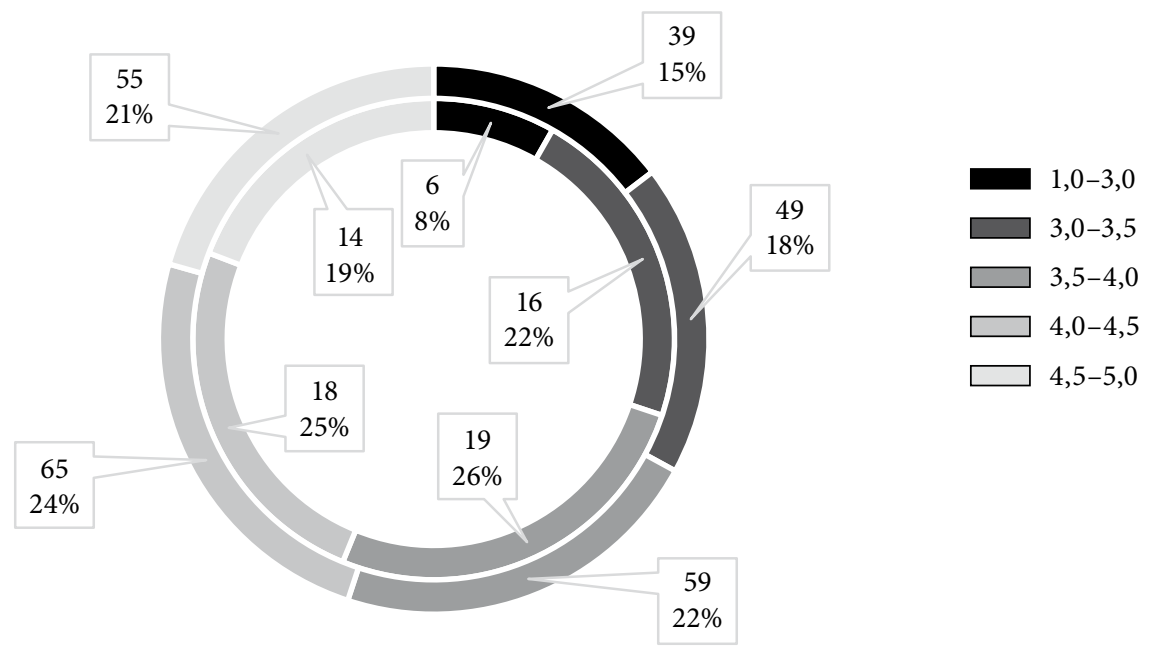


előadásokat és a gyakorlatokat. Másrészt, az új javadalmazási rendszer bevezetése elötti időszak osztályozási gyakorlata alapján csoportokat képeztünk, hogy olyan tantárgy-oktató párokat hasonlítsunk össze, amelyeknél a kezelés előtt hasonló osztályzatok születtek. Az osztályozási gyakorlat alapján öt csoportot képeztünk, amelyek eloszlását a szükített mintán az 1. ábra mutatja. A csoportok eloszlása nagyjából arányosnak tekinthető.

Az egyes osztályozási csoportok szeparált vizsgálata ugyanakkor nagyon lecsökkenti a mintaelemszámot, így interakciós modellt becsültünk, ahol az (1) egyenletben jelölt $\beta$ paramétert minden egyes csoportra külön-külön megbecsültük.

\section{Eredmények}

A kutatás alapja a teljes állású és a részmunkaidős oktatók által kiosztott érdemjegyek különbségének vizsgálata. A becsült hatás akkor valós, ha elfogadjuk azt a feltételezést, hogy a szabályozásváltozás hiányában a két csoport osztályozási trendje hasonló lett volna (tehát teljesül a párhuzamos trend feltevése). A 2. ábra az átlagos osztályzatok alakulását mutatja a vizsgált időszakban. A két csoport által kiosztott érdemjegyek átlaga lényegében állandó volt a szabályozásváltozást megelőző három tavaszi félévben. A szabályozásváltozás enyhe emelkedést idézett elő.

\section{2. ábra}

Az átlagos érdemjegyek alakulása szemeszterenként

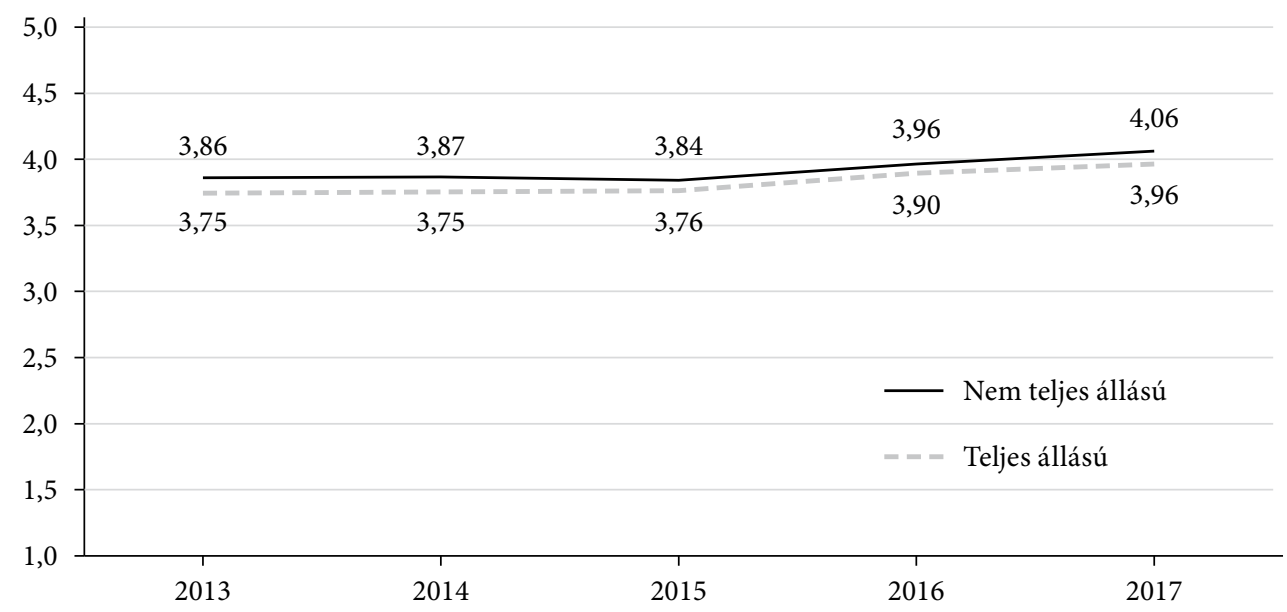

A hatás pontos meghatározása érdekében az (1) egyenlet becslését végeztük el. A 3. táblázat a becslés eredményeit mutatja a teljesítési arányra és az átlagos érdemjegyre (a szúkített mintán). Az első két oszlop a teljes mintát tartalmazza, majd a harmadik és negyedik oszlopok csak a gyakorlati kurzusok részmintáját, míg az ötödik és hatodik oszlopok az elméleti kurzusok (előadások) részmintáját mutatják. 
3. táblázat

A fix hatás regressziós becslésének eredményei

\begin{tabular}{|c|c|c|c|c|c|c|}
\hline \multirow[t]{2}{*}{ Megnevezés } & \multicolumn{2}{|c|}{ Teljes minta } & \multicolumn{2}{|c|}{ Gyakorlati kurzusok } & \multicolumn{2}{|c|}{ Elméleti kurzusok } \\
\hline & $\begin{array}{l}\text { teljesítési } \\
\text { arány }\end{array}$ & érdemjegy & $\begin{array}{l}\text { teljesítési } \\
\text { arány }\end{array}$ & érdemjegy & $\begin{array}{l}\text { teljesítési } \\
\text { arány }\end{array}$ & érdemjegy \\
\hline Jogosult & $\begin{array}{c}0,004 \\
(0,007)\end{array}$ & $\begin{array}{c}0,072 \\
(0,054)\end{array}$ & $\begin{array}{c}0,002 \\
(0,011)\end{array}$ & $\begin{array}{c}0,057 \\
(0,068)\end{array}$ & $\begin{array}{c}0,007 \\
(0,008)\end{array}$ & $\begin{array}{c}0,089 \\
(0,066)\end{array}$ \\
\hline Felvételi pontszám & $\begin{array}{l}0,001^{\star * *} \\
(0,000)\end{array}$ & $\begin{array}{l}0,012^{\star * *} \\
(0,001)\end{array}$ & $\begin{array}{l}0,001^{\star * *} \\
(0,000)\end{array}$ & $\begin{array}{l}0,012^{\star * *} \\
(0,001)\end{array}$ & $\begin{array}{l}0,001^{\star * *} \\
(0,000)\end{array}$ & $\begin{array}{l}0,012^{\star * *} \\
(0,002)\end{array}$ \\
\hline Log(létszám) & $\begin{array}{c}-0,005 \\
(0,005)\end{array}$ & $\begin{array}{l}-0,086^{\star * *} \\
(0,030)\end{array}$ & $\begin{array}{c}-0,005 \\
(0,008)\end{array}$ & $\begin{array}{l}-0,103^{\star *} \\
(0,045)\end{array}$ & $\begin{array}{c}-0,007 \\
(0,011)\end{array}$ & $\begin{array}{c}-0,080 \\
(0,062)\end{array}$ \\
\hline $\begin{array}{l}\text { Szemeszter } \\
\text { kétértékű változók }\end{array}$ & igen & igen & igen & igen & igen & igen \\
\hline$N$ & 1811 & 1811 & 1084 & 1084 & 727 & 727 \\
\hline$R^{2}$ & 0,6650 & 0,8492 & 0,6555 & 0,8540 & 0,6973 & 0,8446 \\
\hline
\end{tabular}

Megjegyzés: zárójelben a tantárgy-oktató párokra klaszterezett standard hibák.

${ }^{* * *} 1$ százalékon, ${ }^{* *} 5$ százalékon, ${ }^{*} 10$ százalékon szignifikáns.

A kontrollváltozók közül a magasabb felvételi pontszám ceteris paribus magasabb érdemjeggyel és nagyobb teljesítési (tehát alacsonyabb bukási) aránnyal párosul, ami arra utal, hogy a felvételi pontszám a képességek jó közelítő változója. Ez megegyezik Nagy és szerzőtársai [2018] eredményeivel. A felvételi pontszám mindegyik regresszióban minden szokásos szinten szignifikáns. Emellett a nagyobb létszámú kurzusokat rosszabb érdemjegyekkel végzik el a hallgatók, ez azonban már csak a gyakorlatokra igaz, az elméleti kurzusokra nem. Ez szintén összecseng a várakozásokkal, hiszen nagyobb létszámú gyakorlatokon a személyes odafigyelés szerepe sokkal kisebb, emiatt pedig a diákok gyengébb teljesítményt nyújthatnak. Az elméleti órákon a személyes interakciók lehetősége eleve korlátozott, így a nagyobb létszám kevésbé problematikus. Érdekes módon a teljesítési arányra nincs hatása a létszámnak, csak az átlagos osztályzatokra.

Az új javadalmazási rendszer bevezetésének nincs érzékelhetö hatása az aggregált adatok alapján. A hatások ugyanakkor nem homogének, az interakciós modellben (4. táblázat) már tapasztalhatók szignifikáns változások. A becslés során tantárgyoktató szinten klaszterezett standard hibákat használtunk, azonban a paraméterek szignifikanciája érdemben nem változik, ha oktatóra vagy tantárgyra klaszterezett standard hibákat alkalmazunk.

Az eredmények alapján a felvételi pontszám továbbra is szignifikáns minden esetben, a létszám pedig csak az osztályzatokra hat, a bukási arányra nem, és csak gyakorlati tárgyaknál, elméleti kurzusoknál szintén nem.

Az eredmények azt mutatják, hogy a legrosszabb érdemjegyekkel záruló tárgyaknál (tantárgy-oktató pároknál) láthatók szignifikáns hatások, a többi esetben lényegében nem mutatható ki érdemi eltérés az új javadalmazási rendszer bevezetése után. Az elöbbi tantárgyaknál viszont 0,3-0,4 közötti értékkel növekedtek meg az átlagos 
4. táblázat

Az új javadalmazási rendszer bevezetésének hatása különböző átlagos osztályzatok esetén

\begin{tabular}{|c|c|c|c|c|c|c|}
\hline \multirow[t]{2}{*}{ Megnevezés } & \multicolumn{2}{|c|}{ Teljes minta } & \multicolumn{2}{|c|}{ Gyakorlati kurzusok } & \multicolumn{2}{|c|}{ Elméleti kurzusok } \\
\hline & $\begin{array}{l}\text { teljesítési } \\
\text { arány }\end{array}$ & érdemjegy & $\begin{array}{l}\text { teljesítési } \\
\text { arány }\end{array}$ & érdemjegy & $\begin{array}{l}\text { teljesítési } \\
\text { arány }\end{array}$ & érdemjegy \\
\hline Felvételi pontszám & $\begin{array}{l}0,001^{\star * *} \\
(0,000)\end{array}$ & $\begin{array}{l}0,012^{\star * *} \\
(0,001)\end{array}$ & $\begin{array}{l}0,001^{\star * *} \\
(0,000)\end{array}$ & $\begin{array}{l}0,011^{\star * *} \\
(0,001)\end{array}$ & $\begin{array}{l}0,001^{\star * *} \\
(0,000)\end{array}$ & $\begin{array}{l}0,012^{\star * *} \\
(0,002)\end{array}$ \\
\hline Log(létszám) & $\begin{array}{c}-0,004 \\
(0,005)\end{array}$ & $\begin{array}{l}-0,082^{\star \star \star} \\
(0,029)\end{array}$ & $\begin{array}{c}-0,002 \\
(0,008)\end{array}$ & $\begin{array}{c}-0,090^{\star *} \\
(0,043)\end{array}$ & $\begin{array}{c}-0,008 \\
(0,011)\end{array}$ & $\begin{array}{c}-0,089 \\
(0,059)\end{array}$ \\
\hline
\end{tabular}

Átlagos osztályzat kezelés előtt, referenciacsoport: 4,5-5,0

\begin{tabular}{lclllll}
$1,0-3,0$ & $-0,080^{* *}$ & $-0,614^{* * *}$ & $-0,116^{* * *}$ & $-1,580^{* * *}$ & $-0,093^{* * *}$ & $-1,245^{* * *}$ \\
$3,0-3,5$ & $(0,035)$ & $(0,218)$ & $(0,009)$ & $(0,058)$ & $(0,023)$ & $(0,141)$ \\
& $-0,032$ & $-0,380^{* *}$ & $-0,051^{* * *}$ & $-1,109^{* * *}$ & $-0,031^{*}$ & $-0,796^{* * *}$ \\
$3,5-4,0$ & $(0,022)$ & $(0,156)$ & $(0,009)$ & $(0,052)$ & $(0,018)$ & $(0,109)$ \\
& 0,002 & $-0,237^{* * *}$ & $-0,028^{* * *}$ & $-0,680^{* * *}$ & $-0,068^{* * *}$ & $-0,637^{* * *}$ \\
$4,0-4,5$ & $(0,014)$ & $(0,084)$ & $(0,009)$ & $(0,056)$ & $(0,015)$ & $(0,089)$ \\
& $0,014^{*}$ & $-0,102^{* *}$ & 0,007 & $-0,650^{* * *}$ & $-0,058^{* * *}$ & 0,019 \\
\hline Jogosult & $(0,008)$ & $(0,048)$ & $(0,005)$ & $(0,037)$ & $(0,012)$ & $(0,080)$ \\
& $-0,008$ & $-0,062$ & $-0,012$ & $-0,051$ & $-0,004$ & $-0,129^{*}$ \\
& $(0,006)$ & $(0,057)$ & $(0,010)$ & $(0,072)$ & $(0,006)$ & $(0,076)$ \\
\hline
\end{tabular}

Jogosult $\times$ Átlagos osztályzat kezelés előtt, referenciacsoport: 4,5-5,0

\begin{tabular}{lcccccc}
$1,0-3,0$ & $0,064^{* * *}$ & $0,348^{* * *}$ & $0,074^{\star * *}$ & $0,353^{* * *}$ & $0,048^{* * *}$ & $0,378^{\star * *}$ \\
& $(0,015)$ & $(0,075)$ & $(0,019)$ & $(0,084)$ & $(0,018)$ & $(0,110)$ \\
$3,0-3,5$ & 0,011 & $0,200^{* * *}$ & 0,011 & 0,147 & 0,014 & $0,322^{\star * *}$ \\
& $(0,013)$ & $(0,077)$ & $(0,016)$ & $(0,095)$ & $(0,013)$ & $(0,089)$ \\
$3,5-4,0$ & 0,001 & 0,101 & 0,004 & 0,102 & $-0,003$ & 0,138 \\
& $(0,009)$ & $(0,062)$ & $(0,010)$ & $(0,072)$ & $(0,011)$ & $(0,097)$ \\
$4,0-4,5$ & $-0,002$ & 0,057 & $-0,004$ & 0,005 & 0,003 & $0,178^{\star *}$ \\
& $(0,005)$ & $(0,051)$ & $(0,008)$ & $(0,063)$ & $(0,008)$ & $(0,075)$ \\
Szemeszter & igen & igen & igen & igen & igen & igen \\
kétértékü változók & & & & & & \\
\hline$N$ & 1811 & 1811 & 1084 & 1084 & 727 & 727 \\
$R^{2}$ & 0,6813 & 0,8542 & 0,6750 & 0,8590 & 0,7058 & 0,8499 \\
\hline
\end{tabular}

Megjegyzés: zárójelben a tantárgy-oktató párokra klaszterezett standard hibák.

${ }^{* * *} 1$ százalékon, ${ }^{* *} 5$ százalékon, ${ }^{*} 10$ százalékon szignifikáns.

érdemjegyek a teljes állású oktatóknál, amelyek az alacsony kiindulási érték miatt körülbelül 10 százalékos javulásnak felelnek meg. A javulás két okra vezethető viszsza. Egyrészt, az adott tantárgyakat sikerrel teljesítők aránya jelentősen megemelkedett (főként a gyakorlatok esetén). A bukási arány igen jelentősen, mintegy 7 százalékponttal csökkent gyakorlatok esetében, és 5 százalékponttal az elméleti kurzusokéban. A kiinduló bukási arányt (18 százalék gyakorlatok és 15 százalék elméleti 
kurzusok esetében) figyelembe véve ez körülbelül 30-40 százalékos csökkenést jelez, a diákok képességeire való kontrollálás után. A bukási arány csökkenése nagy valószínüséggel azt jelenti, hogy azok a hallgatók, akik az elégtelen és az elégséges osztályzatok határán álltak, elégségest kaptak. Pusztán e hatás miatt (minden mást változatlannak véve) már körülbelül 0,07 körüli értékkel emelkedett meg az átlagos osztályzat. Az átlagos osztályzatok azonban ennél lényegesen jobban, mintegy 0,30,4-del nőttek, tehát minden osztályzatnál megfigyelhető javulás, nem csak az elégteleneknél (azoknál a tantárgy-oktatók pároknál, ahol a legrosszabb érdemjegyek születtek a szabályozásváltozás bevezetése előtt).

A 3,0 és 3,5 közötti kurzusoknál már csak az elöadások esetében figyelhető meg javulás az érdemjegyekben. Az ennél is jobb átlagos érdemjegyeket produkáló kurzusok esetében pedig az új javadalmazási rendszer bevezetése nem gyakorol szignifikáns hatást.

Az eredmények robusztusságának vizsgálatához a mintába belevettük az öszi félévek tárgyait is, kivéve a 2016/2017. tanév őszi félévét, hiszen éppen akkor zajlott az új szabályozás implementálása. A becslés eredményei alapvetően megegyeznek a 4. táblázatban közölt eredményekkel (Függelék F1. táblázat).

$\mathrm{Az}$ adatbázis szintén lehetővé teszi, hogy megvizsgáljuk az új szabályozás hatását egy évvel a bevezetése után (tehát csak a 2016/2017. tanévig vizsgálva az adatsorokat). Ezáltal láthatóvá válik, hogy a hatások milyen gyorsan jelentek meg, illetve összevethető azok nagysága is. Az eredmények azt mutatják, hogy az új szabályozás bevezetése után azonnal megjelent a hatás, bár az első évben még valamelyest mérsékeltebb volt a nagysága (Függelék F2. táblázat). Az egyetemi oktatók tehát gyorsan reagáltak a differenciált javadalmazási rendszer bevezetésére, a bemutatott hatások nagy része rögtön a bevezetést követő szemeszterben tetten érhető volt.

Az eredmények tehát azt mutatják, hogy az érintett tantárgyak és oktatók esetében általában jobban teljesítettek a hallgatók. Ez kétféle hatásmechanizmussal is összhangban van. Egyrészt, az eredmények konzisztensek a jegyinfláció jelenségével. Az érintett oktatók csökkentették a követelményeket, így a hallgatók jobb érdemjegyeket érhettek el, ennek következtében jobb hallgatói értékelést adhattak az oktatónak. Ez kedvezőtlen jelenség, hiszen arra utal, hogy az oktatás színvonala csökkent, és kevesebb tudással is teljesíteni lehetett nehéz tantárgyakat.

Másrészt viszont az is elképzelhető, hogy az oktatók az új javadalmazási rendszer következtében jobban felkészültek az órákra, nagyobb hangsúlyt fektettek arra, hogy a hallgatók megértsék a tananyagot, ami - az oktatói teljesítmény növekedésén keresztül - jobb osztályzatokat eredményezett. Ebben az esetben éppen hogy kedvező változások történtek, a hallgatók vélhetően több tudást szereztek meg az órákon.

A két hatás elválasztása az adatbázis alapján nem lehetséges. Az érintett hallgatók hosszabb távú nyomon követése, esetleg az oktatók és a hallgatók kérdőíves vagy mélyinterjús megkérdezése adhat támpontokat. Ugyanakkor az alkalmazkodás nagyon gyorsan (lényegében azonnal) megjelent, és alapvetően olyan oktatókat érintett, akik régóta tanítják az adott tantárgyat az egyetemen. Ebben az esetben valamivel kisebb a valószínüsége, hogy az oktatói teljesítmény javulása okozta a jobb érdemjegyeket, bár ezt az állítást további kutatások során érdemes lenne erősebb érvekkel alátámasztani. 


\section{Összefoglalás}

Kutatásunk során azt vizsgáltuk, hogy az egyetemi oktatók hallgatói értékelésének beemelése a javadalmazási rendszerbe növeli-e a jegyinflációt. Eredményeink egy magyarországi egyetem szabályozásváltozása okozta természetes kísérleten alapulnak.

Az eredmények azt mutatják, hogy a pénzügyi javadalmazásnak volt hatása mind az átlagos érdemjegyekre, mind az elégtelen osztályzatok arányára is. A hatások ugyanakkor nem egységesek, és alapvetően a legrosszabb osztályzatú, legmagasabb bukási aránnyal jellemezhető tantárgyakat érintették. A hatások nagysága nem elhanyagolható mértékű, ugyanakkor nem állítható, hogy a szabályozásváltozás által érintett minden oktató könnyített volna a számonkérésen, és a hallgatók sokkal könnyebben szerezhetnek ezentúl jobb jegyeket. Ezzel kapcsolatban azonban két fontos korlátra kell felhívni a figyelmet.

Egyrészt, az új rendszer bevezetése óta mindössze két tanév telt el. A hosszú távú hatások értékeléséhez néhány év múlva érdemes újra elvégezni az elemzést és megfigyelni a változásokat. Ugyanakkor a hosszabb adatsor hátránya, hogy csökken azon tantárgy-oktató párok száma, amelyek mindegyik tanévben vagy legalább a tanévek többségében előfordulnak. Ez hatványozottan igaz a nem teljes állású alkalmazottakra, ahol nagyobb a fluktuáció (demonstrátorok, PhD-hallgatók néhány évente váltakoznak). Ez csökkentheti a hosszú távú elemzések megbízhatóságát.

Másrészt, az elemzés azt mutatja, hogy a jegyek hogyan változtak adott tantárgyakból. Azt viszont nem tudjuk megfigyelni, hogy az érdemjegyek változása mögött valós teljesítmények vagy jegyinfláció húzódik meg. A leírt hatásmechanizmusok nemcsak engedékenyebb osztályozás esetén működnek, hanem akkor is, ha az oktató több erőfeszítést tesz az oktatásba, vagy bizonyos célcsoportokra jobban összpontosít, tehát például nagyobb hangsúlyt fektet arra, hogy a tantárgy alapjait mindenki megértse, és ezáltal csökken a bukások száma.

A meglévő adatok alapján nem tudjuk eldönteni ezt a kérdést. A két hatás szeparálására jó megoldásnak tünhet egy, az oktatók és a hallgatók körében elvégzendő kérdőíves vagy kvalitatív kutatás. Ez viszont túlmutat a jelen tanulmány keretein.

\section{Hivatkozások}

Alauddin, M.-Kifle, T. [2014]: Does the student evaluation of teaching instrument really measure instructors' teaching effectiveness? An econometric analysis of students' perceptions in economics courses. Economic Analysis and Policy, Vol. 44. No. 2. 156-168. o. https://doi.org/10.1016/j.eap.2014.05.009.

ANDRAde, E. C.-Rocha, B. P. [2012]: Factors affecting the student evaluation of teaching scores: evidence from panel data estimation. Estudos Econômicos (São Paulo), Vol. 42. No. 1. 129-150. o. https://doi.org/10.1590/S0101-41612012000100005.

BABCOCK, P.-MARKs, M. [2011]: The falling time cost of college. Evidence from half a century of time use data. Review of Economics and Statistics, Vol. 93. No. 2. 468-478. o. https:// doi.org/10.1162/rest_a_00093. 
Bauer, T. K.-Grave, B. S. [2011]: Performance-related funding of universities - does more competition lead to grade inflation? Ruhr Economic Paper, No. 288. https:/doi. org/10.2139/ssrn.1954693.

Berezvai Zombor [2018]: Megvásárolható-e a jobb értékelés jobb osztályzattal? Eredmények a Budapesti Corvinus Egyetem hallgatói véleményezési rendszere alapján. Kézirat, Budapesti Corvinus Egyetem Stratégiai és Minőségfejlesztési Igazgatóság.

Boring, A. [2017]: Gender biases in student evaluations of teaching. Journal of Public Economics, Vol. 145. 27-41. o. https://doi.org/10.1016/j.jpubeco.2016.11.006.

Boring, A.-Отtoboni, K.-STARк, P. B. [2016]: Student evaluations of teaching (mostly) do not measure teaching effectiveness. ScienceOpen, 1-11. o. https://doi.org/10.14293/S21991006.1.SOR-EDU.AETBZC.v1.

Butcher, K. F.-McEwan, P. J.-Weerapana, A. [2014]: The Effects of an Anti-GradeInflation Policy at Wellesley College. The Journal of Economic Perspectives, Vol. 28. No. 3. 189-204. o. https://doi.org/10.1257/jep.28.3.189.

CHENG, D. A. [2015]: Effects of professorial tenure on undergraduate ratings of teaching performance. Education Economics, Vol. 23. No. 3. 338-357. o. https://doi.org/10.1080/0964 5292.2013.826632.

Сно, D.-Сно, J. [2017]: Does more accurate knowledge of course grade impact teaching evaluation? Education Finance and Policy, Vol. 12. No. 2. 224-240. o. https://doi.org/10.1162/ EDFP_a_00197.

Davies, M.-Hirschberg, J.-Lye, J.-Johnston, C.-McDonald, I. [2007]: Systematic influences on teaching evaluations: The case for caution. Australian Economic Papers, Vol. 46. No. 1. 18-38. o. https://doi.org/10.1111/j.1467-8454.2007.00303.x.

EIszLer, C. F. [2002]: College students' evaluations of teaching and grade inflation. Research in Higher Education, Vol. 43. No. 4. 483-501. o. https://doi.org/10.1023/A:1015579817194.

ELEK PÉTER-LőRINCz LÁszLó [2015]: Az effektív társasági adókulcs rugalmassága Magyarországon a 2009-2011 közötti adókulcscsökkentés alapján. Közgazdasági Szemle, 62. évf. 1. sz. 27-47. o.

EwING, A. M. [2012]: Estimating the impact of relative expected grade on student evaluations of teachers. Economics of Education Review, Vol. 31. No. 1. 141-154. o. https://doi. org/10.1016/j.econedurev.2011.10.002.

Hornstein, H. A. [2017]: Student evaluations of teaching are an inadequate assessment tool for evaluating faculty performance. Cogent Education, Vol. 4. No. 1304016. https://doi.org /10.1080/2331186X.2017.1304016.

Isely, P.-Singh, H. [2005]: Do Higher Grades Lead to Favorable Student Evaluations? The Journal of Economic Education, Vol. 36. No. 1. 29-42. o. https://doi.org/10.3200/ JECE.36.1.29-42.

Jewell, R. T.-McPherson, M. A.-Tieslau, M. A. [2013]: Whose fault is it? Assigning blame for grade inflation in higher education. Applied Economics, Vol. 45. No. 9. 1185-1200. o. https://doi.org/10.1080/00036846.2011.621884.

Korn, M. [2018]: You graduated cum laude? So did everyone else. The Wall Street Journal, július 2. https://www.wsj.com/articles/you-graduated-cum-laude-so-did-everyoneelse-1530523801.

LukÁts Gergely DÁNIEL [2019]: A jegyinfláció hatása az oktatók hallgatói véleményezésére. OTDK-dolgozat, Budapesti Müszaki és Gazdaságtudományi Egyetem.

Macfadyen, L. P.-Dawson, S.-Prest, S.-GašEvić, D. [2016]: Whose feedback? A multilevel analysis of student completion of end-of-term teaching evaluations. Assessment \& 
Evaluation in Higher Education, Vol. 41. No. 6. 821-839. o. https://doi.org/10.1080/02602 938.2015.1044421.

McPherson, M. A.-Jewell, R. T.-Kim, M. [2009]: What Determines Student Evaluation Scores? A Random Effects Analysis of Undergraduate Economics Classes. Eastern Economic Journal, Vol. 35. No. 1. 37-51. o. https://doi.org/10.1057/palgrave.eej.9050042.

Meyer, B. D.-Viscusi, W. K.-Durbin, D. L. [1995]: Workers' Compensation and Injury Duration: Evidence from a Natural Experiment. American Economic Review, Vol. 85. 322-340. o. https://doi.org/10.3386/w3494.

Nagy Marcell-Molontay Roland-Csabay Bálint [2018]: Predictive Power of Admission Point Score and its Variants on Academic Performance. 2nd Danube Conference for Higher Education Management, Book of Abstracts, 16-17. o.

Nowell, C. [2007]: The Impact of Relative Grade Expectations on Student Evaluation of Teaching. International Review of Economics Education, Vol. 6. No. 2. 42-56. o. https:// doi.org/10.1016/S1477-3880(15)30104-3.

Nowell, C.-Gale, L. R.-Handley, B. [2010]: Assessing faculty performance using student evaluations of teaching in an uncontrolled setting. Assessment \& Evaluation in Higher Education, Vol. 35. No. 4. 463-475. o. https://doi.org/10.1080/02602930902862875.

Rojstaczer, S. [2016]: Grade inflation at American colleges and universities. http://www. gradeinflation.com.

SELdin, P. [1998]: How colleges evaluate teaching: 1988 vs. 1998: Practices and trends in the evaluation of faculty performance. AAHE Bulletin, Vol. 50. 3-7. o.

Spooren, P.-Brockx, B.-Mortelmans, D. [2013]: On the validity of student evaluation of teaching: The state of the art. Review of Educational Research, Vol. 83. No. 4. 598-642. o. https://doi.org/10.3102/0034654313496870.

STARK, P. [2013]: Do student evaluations measure teaching effectiveness? Berkeley Blog, http:// blogs.berkeley.edu/2013/10/14/do-student-evaluations-measure-teaching-effectiveness/.

Stroebe, W. [2016]: Why good teaching evaluations may reward bad teaching: On grade inflation and other unintended consequences of student evaluations. Perspectives on Psychological Science, Vol. 11. No. 6. 800-816. o. https://doi.org/10.1177/1745691616650284. Ware, J. E.-Williams, R. G. [1975]: The Dr. Fox effect: a study of lecturer effectiveness and ratings of instruction. Academic Medicine, Vol. 50. No. 2. 149-156. o. https://doi. org/10.1097/00001888-197502000-00006.

WiLson, B. P. [1999]: The phenomenon of grade inflation in higher education. Phi Kappa Phi Journal, Vol. 79. 38. o.

Youmans, R. J.-JeE, B. D. [2007]: Fudging the numbers: Distributing chocolate influences student evaluations of an undergraduate course. Teaching of Psychology, Vol. 34. No. 4. 245-247. o. https://doi.org/10.1080/00986280701700318. 


\section{Függelék}

F1. táblázat

Tavaszi és öszi féléveket (kivéve a 2016/2017. tanév őszi félévét) is tartalmazó mintán végzett becslés eredményei

\begin{tabular}{|c|c|c|c|c|c|c|}
\hline \multirow[t]{2}{*}{ Megnevezés } & \multicolumn{2}{|c|}{ Teljes minta } & \multicolumn{2}{|c|}{ Gyakorlati kurzusok } & \multicolumn{2}{|c|}{ Elméleti kurzusok } \\
\hline & $\begin{array}{l}\text { teljesítési } \\
\text { arány }\end{array}$ & érdemjegy & $\begin{array}{l}\text { teljesítési } \\
\text { arány }\end{array}$ & érdemjegy & $\begin{array}{l}\text { teljesítési } \\
\text { arány }\end{array}$ & érdemjegy \\
\hline Felvételi pontszám & $\begin{array}{l}0,001^{* * *} \\
(0,000)\end{array}$ & $\begin{array}{l}0,010^{\star * *} \\
(0,001)\end{array}$ & $\begin{array}{l}0,001^{* * *} \\
(0,000)\end{array}$ & $\begin{array}{l}0,010^{\star * *} \\
(0,001)\end{array}$ & $\begin{array}{l}0,001^{\star * *} \\
(0,000)\end{array}$ & $\begin{array}{l}0,011^{* * *} \\
(0,001)\end{array}$ \\
\hline Log(létszám) & $\begin{array}{c}0,002 \\
(0,004)\end{array}$ & $\begin{array}{c}-0,035^{\star} \\
(0,020)\end{array}$ & $\begin{array}{c}-0,000 \\
(0,005)\end{array}$ & $\begin{array}{c}-0,047^{\star} \\
(0,029)\end{array}$ & $\begin{array}{c}0,013 \\
(0,011)\end{array}$ & $\begin{array}{c}-0,001 \\
(0,051)\end{array}$ \\
\hline \multicolumn{7}{|c|}{ Átlagos osztályzat kezelés előtt, referenciacsoport: $4,5-5,0$} \\
\hline $1,0-3,0$ & $\begin{array}{c}-0,106^{\star *} \\
(0,042)\end{array}$ & $\begin{array}{c}-0,843^{* * *} \\
(0,204)\end{array}$ & $\begin{array}{c}-0,242^{\star * *} \\
(0,012)\end{array}$ & $\begin{array}{l}-2,806^{\star * *} \\
(0,055)\end{array}$ & $\begin{array}{l}-0,158^{\star * \star} \\
(0,025)\end{array}$ & $\begin{array}{l}-1,632^{\star * *} \\
(0,132)\end{array}$ \\
\hline $3,0-3,5$ & $\begin{array}{c}-0,068^{\star *} \\
(0,034)\end{array}$ & $\begin{array}{l}-0,655^{\star \star \star} \\
(0,142)\end{array}$ & $\begin{array}{l}-0,054^{\star * *} \\
(0,006)\end{array}$ & $\begin{array}{c}-1,146^{\star * *} \\
(0,037)\end{array}$ & $\begin{array}{c}-0,104^{\star *} \\
(0,041)\end{array}$ & $\begin{array}{c}-1,588^{\star * *} \\
(0,191)\end{array}$ \\
\hline $3,5-4,0$ & $\begin{array}{c}-0,014 \\
(0,011)\end{array}$ & $\begin{array}{l}-0,361^{\star \star \star} \\
(0,059)\end{array}$ & $\begin{array}{l}-0,100^{\star * \star} \\
(0,011)\end{array}$ & $\begin{array}{c}-1,180^{\star * *} \\
(0,080)\end{array}$ & $\begin{array}{l}-0,079^{\star * \star} \\
(0,013)\end{array}$ & $\begin{array}{l}-0,703^{\star * \star} \\
(0,075)\end{array}$ \\
\hline $4,0-4,5$ & $\begin{array}{c}0,003 \\
(0,006) \\
\end{array}$ & $\begin{array}{l}-0,194^{* * *} \\
(0,035)\end{array}$ & $\begin{array}{c}0,006 \\
(0,004)\end{array}$ & $\begin{array}{l}-0,671^{\star * *} \\
(0,029)\end{array}$ & $\begin{array}{c}-0,068^{\star * *} \\
(0,011)\end{array}$ & $\begin{array}{c}-0,048 \\
(0,069)\end{array}$ \\
\hline Jogosult & $\begin{array}{c}-0,006 \\
(0,006)\end{array}$ & $\begin{array}{c}-0,065 \\
(0,048)\end{array}$ & $\begin{array}{c}-0,011 \\
(0,008)\end{array}$ & $\begin{array}{c}-0,067 \\
(0,057)\end{array}$ & $\begin{array}{c}0,004 \\
(0,008)\end{array}$ & $\begin{array}{c}-0,074 \\
(0,077)\end{array}$ \\
\hline \multicolumn{7}{|c|}{ Jogosult $\times$ Átlagos osztályzat kezelés előtt, referenciacsoport: 4,5-5,0 } \\
\hline $1,0-3,0$ & $\begin{array}{l}0,043^{\star * *} \\
(0,015)\end{array}$ & $\begin{array}{l}0,289^{\star * *} \\
(0,066)\end{array}$ & $\begin{array}{l}0,064^{* * *} \\
(0,015)\end{array}$ & $\begin{array}{l}0,340^{\star * *} \\
(0,070)\end{array}$ & $\begin{array}{c}0,010 \\
(0,027)\end{array}$ & $\begin{array}{l}0,229^{\star *} \\
(0,110)\end{array}$ \\
\hline $3,0-3,5$ & $\begin{array}{c}0,007 \\
(0,010)\end{array}$ & $\begin{array}{l}0,175^{\star * *} \\
(0,064)\end{array}$ & $\begin{array}{c}0,012 \\
(0,012)\end{array}$ & $\begin{array}{l}0,158^{\star *} \\
(0,067)\end{array}$ & $\begin{array}{c}0,002 \\
(0,014)\end{array}$ & $\begin{array}{c}0,226^{\star *} \\
(0,098)\end{array}$ \\
\hline $3,5-4,0$ & $\begin{array}{c}0,000 \\
(0,007)\end{array}$ & $\begin{array}{c}0,084 \\
(0,053)\end{array}$ & $\begin{array}{c}0,005 \\
(0,008)\end{array}$ & $\begin{array}{c}0,0942 \\
(0,057)\end{array}$ & $\begin{array}{c}-0,007 \\
(0,010)\end{array}$ & $\begin{array}{c}0,079 \\
(0,089)\end{array}$ \\
\hline $4,0-4,5$ & $\begin{array}{c}0,002 \\
(0,005)\end{array}$ & $\begin{array}{c}0,078^{\star} \\
(0,044)\end{array}$ & $\begin{array}{c}0,003 \\
(0,006)\end{array}$ & $\begin{array}{c}0,058 \\
(0,050)\end{array}$ & $\begin{array}{c}-0,003 \\
(0,009)\end{array}$ & $\begin{array}{c}0,114 \\
(0,075)\end{array}$ \\
\hline $\begin{array}{l}\text { Szemeszter } \\
\text { kétértékű változók }\end{array}$ & igen & igen & igen & igen & igen & igen \\
\hline$N$ & 3221 & 3221 & 2014 & 2014 & 1207 & 1207 \\
\hline$R^{2}$ & 0,6634 & 0,8690 & 0,6882 & 0,8800 & 0,6432 & 0,8529 \\
\hline
\end{tabular}

Megjegyzés: zárójelben a tantárgy-oktató párokra klaszterezett standard hibák.

${ }^{* * *} 1$ százalékon, ${ }^{* *} 5$ százalékon, ${ }^{*} 10$ százalékon szignifikáns. 
F2. táblázat

A reform utáni első év vizsgálata (2013/2014. tanévtől 2016/2017. tanévig futó minta)

\begin{tabular}{|c|c|c|c|c|c|c|}
\hline \multirow[t]{2}{*}{ Megnevezés } & \multicolumn{2}{|c|}{ Teljes minta } & \multicolumn{2}{|c|}{ Gyakorlati kurzusok } & \multicolumn{2}{|c|}{ Elméleti kurzusok } \\
\hline & $\begin{array}{l}\text { teljesítési } \\
\text { arány }\end{array}$ & érdemjegy & $\begin{array}{l}\text { teljesítési } \\
\text { arány }\end{array}$ & érdemjegy & $\begin{array}{l}\text { teljesítési } \\
\text { arány }\end{array}$ & érdemjegy \\
\hline Felvételi pontszám & $\begin{array}{l}0,001^{\star \star \star} \\
(0,000)\end{array}$ & $\begin{array}{l}0,011^{\star * *} \\
(0,001)\end{array}$ & $\begin{array}{l}0,001^{\star * *} \\
(0,000)\end{array}$ & $\begin{array}{l}0,011^{\star \star *} \\
(0,002)\end{array}$ & $\begin{array}{l}0,001^{\star *} \\
(0,000)\end{array}$ & $\begin{array}{l}0,012^{\star * *} \\
(0,002)\end{array}$ \\
\hline Log(létszám) & $\begin{array}{c}-0,003 \\
(0,006)\end{array}$ & $\begin{array}{l}-0,083^{\star *} \\
(0,033)\end{array}$ & $\begin{array}{c}-0,001 \\
(0,010)\end{array}$ & $\begin{array}{c}-0,090^{*} \\
(0,052)\end{array}$ & $\begin{array}{c}-0,007 \\
(0,014)\end{array}$ & $\begin{array}{c}-0,090 \\
(0,070)\end{array}$ \\
\hline \multicolumn{7}{|c|}{ Átlagos osztályzat kezelés előtt, referenciacsoport: 4,5-5,0 } \\
\hline $1,0-3,0$ & $\begin{array}{c}-0,078^{\star *} \\
(0,034)\end{array}$ & $\begin{array}{c}-0,641^{\star * *} \\
(0,220)\end{array}$ & $\begin{array}{c}-0,117^{\star * *} \\
(0,011)\end{array}$ & $\begin{array}{c}-1,444^{* * *} \\
(0,057)\end{array}$ & $\begin{array}{l}-0,089^{\star * *} \\
(0,030)\end{array}$ & $\begin{array}{c}-1,320^{\star * \star} \\
(0,163)\end{array}$ \\
\hline $3,0-3,5$ & $\begin{array}{c}-0,041 \\
(0,025)\end{array}$ & $\begin{array}{l}-0,432^{\star * *} \\
(0,165)\end{array}$ & $\begin{array}{l}-0,049^{\star * *} \\
(0,008)\end{array}$ & $\begin{array}{c}-1,130^{\star * *} \\
(0,041)\end{array}$ & $\begin{array}{c}-0,016 \\
(0,025)\end{array}$ & $\begin{array}{c}-0,986^{\star * *} \\
(0,133)\end{array}$ \\
\hline $3,5-4,0$ & $\begin{array}{c}-0,009 \\
(0,017)\end{array}$ & $\begin{array}{l}-0,342^{* * *} \\
(0,093)\end{array}$ & $\begin{array}{l}-0,035^{\star * \star} \\
(0,011)\end{array}$ & $\begin{array}{l}-0,692^{\star \star \star} \\
(0,058)\end{array}$ & $\begin{array}{l}-0,069^{* * *} \\
(0,019)\end{array}$ & $\begin{array}{c}-0,868^{\star * *} \\
(0,104)\end{array}$ \\
\hline $4,0-4,5$ & $\begin{array}{c}0,010 \\
(0,010)\end{array}$ & $\begin{array}{c}-0,083 \\
(0,053)\end{array}$ & $\begin{array}{l}0,014^{\star * \star} \\
(0,004)\end{array}$ & $\begin{array}{l}-0,480^{* * *} \\
(0,029)\end{array}$ & $\begin{array}{l}-0,073^{\star * *} \\
(0,019)\end{array}$ & $\begin{array}{c}-0,257^{* *} \\
(0,104)\end{array}$ \\
\hline Jogosult & $\begin{array}{c}-0,001 \\
(0,007)\end{array}$ & $\begin{array}{c}-0,037 \\
(0,065)\end{array}$ & $\begin{array}{c}-0,003 \\
(0,010)\end{array}$ & $\begin{array}{c}-0,027 \\
(0,083)\end{array}$ & $\begin{array}{c}-0,001 \\
(0,008)\end{array}$ & $\begin{array}{c}-0,094 \\
(0,092)\end{array}$ \\
\hline \multicolumn{7}{|c|}{ Jogosult $\times$ Átlagos osztályzat kezelés előtt, referenciacsoport: 4,5-5,0 } \\
\hline $1,0-3,0$ & $\begin{array}{l}0,060^{* * *} \\
(0,014)\end{array}$ & $\begin{array}{l}0,307^{* * *} \\
(0,092)\end{array}$ & $\begin{array}{l}0,071^{\star * *} \\
(0,017)\end{array}$ & $\begin{array}{l}0,304^{* * *} \\
(0,103)\end{array}$ & $\begin{array}{l}0,043^{* *} \\
(0,020)\end{array}$ & $\begin{array}{l}0,351^{* * *} \\
(0,134)\end{array}$ \\
\hline $3,0-3,5$ & $\begin{array}{c}-0,000 \\
(0,014)\end{array}$ & $\begin{array}{l}0,165^{\star *} \\
(0,072)\end{array}$ & $\begin{array}{c}0,005 \\
(0,018)\end{array}$ & $\begin{array}{c}0,147^{\star} \\
(0,082)\end{array}$ & $\begin{array}{c}-0,001 \\
(0,015)\end{array}$ & $\begin{array}{l}0,246^{\star *} \\
(0,097)\end{array}$ \\
\hline $3,5-4,0$ & $\begin{array}{c}0,002 \\
(0,009)\end{array}$ & $\begin{array}{c}0,073 \\
(0,070)\end{array}$ & $\begin{array}{c}0,004 \\
(0,012)\end{array}$ & $\begin{array}{c}0,080 \\
(0,083)\end{array}$ & $\begin{array}{c}-0,001 \\
(0,012)\end{array}$ & $\begin{array}{c}0,095 \\
(0,107)\end{array}$ \\
\hline $4,0-4,5$ & $\begin{array}{r}-0,005 \\
(0,006\end{array}$ & $\begin{array}{c}0,033 \\
(0,054)\end{array}$ & $\begin{array}{c}-0,007 \\
(0,007)\end{array}$ & $\begin{array}{c}0,007 \\
(0,061)\end{array}$ & $\begin{array}{c}-0,001 \\
(0,012)\end{array}$ & $\begin{array}{c}0,108 \\
(0,095)\end{array}$ \\
\hline $\begin{array}{l}\text { Szemeszter } \\
\text { kétértékü változók }\end{array}$ & igen & igen & igen & igen & igen & igen \\
\hline$N$ & 1475 & 1475 & 884 & 884 & 591 & 591 \\
\hline$R^{2}$ & 0,7036 & 0,8716 & 0,7042 & 0,8801 & 0,7143 & 0,8599 \\
\hline
\end{tabular}

Megjegyzés: zárójelben a tantárgy-oktató párokra klaszterezett standard hibák.

${ }^{\star * *} 1$ százalékon, ${ }^{\star *} 5$ százalékon, ${ }^{\star} 10$ százalékon szignifikáns. 